\title{
Photoperiodic Regulation of Cerebral Blood Flow in White-Footed Mice (Peromyscus leucopus)
}

\author{
(D) Jeremy C. Borniger, ${ }^{1,2,3}$ Seth Teplitsky, ${ }^{4}{ }^{\circledR}$ Surya Gnyawali, ${ }^{4}{ }^{\circledR}$ Randy J. Nelson,,${ }^{1,2,3}$ and ${ }^{\circledR}$ Cameron \\ Rink $^{4}$
}

DOI:http://dx.doi.org/10.1523/ENEURO.0058-16.2016

${ }^{1}$ The Behavioral Neuroendocrinology Group, Wexner Medical Center, The Ohio State University, Columbus, Ohio 43210, ${ }^{2}$ Department of Neuroscience, Wexner Medical Center, The Ohio State University, Columbus, Ohio 43210, ${ }^{3}$ Neuroscience Research Institute, Wexner Medical Center, The Ohio State University, Columbus, OH 43210, and

${ }^{4}$ Department of Surgery, Wexner Medical Center, The Ohio State University, Columbus, Ohio 43210

\begin{abstract}
Individuals living outside the tropics need to adjust their behavioral and physiological repertoires throughout the year to adapt to the changing seasons. White-footed mice (Peromyscus leucopus) reduce hippocampal volumes, hippocampal-dependent memory function, long-term potentiation, and alter neurogenesis in response to short (winter-like) day lengths (photoperiods). During winter, these mice putatively shunt energy away from the brain to maximize peripheral thermogenesis, immune function, and survival. We hypothesized that these changes in brain function are accompanied by alterations in brain vasculature. We maintained white-footed mice in short $(8 \mathrm{~h}$ light/16 $\mathrm{h}$ dark) or long (16 $\mathrm{h}$ light/8 $\mathrm{h}$ dark) photoperiods for 8-9 weeks. Mice were then perfused with fluorescein isothiocyanate (FITC)-conjugated tomato (Lycopersicon esculentum) lectin to visualize the perfused cerebrovasculature. Short-day mice reduced hippocampal and cortical capillary density (FITC ${ }^{+}$area); vessels isolated from short day-exposed mice expressed higher mRNA levels of the gelatinase matrix metalloproteinase 2 (MMP2). Additionally, short-day mice reduced cerebral blood flow $\sim 15 \%$ compared with their long-day counterparts, as assessed by laser speckle flowmetry. Immunohistochemistry revealed higher levels of MMP2 in the hippocampus of mice maintained in short days compared with long days, potentially contributing to the observed vascular remodeling. These data demonstrate that a discrete environmental signal (i.e., day length) can substantially alter cerebral blood flow in adult mammals.
\end{abstract}

Key words: brain blood flow; hippocampus; peromyscus; photoperiod

\section{Significance Statement}

Individuals living in nontropical climates show seasonal changes in physiology and behavior primarily controlled by day length (photoperiod). Specifically, white-footed mice (Peromyscus leucopus) display reduced hippocampal function, neurogenesis, and cognitive capacity in response to short days. It is unknown, however, whether these changes are preceded or accompanied by alterations in cerebral blood flow. This study provides evidence that short days elicit a reduction in hippocampal and cortical blood flow, and that this reduction is accompanied by increased mRNA and protein expression of the gelatinase matrix metalloproteinase 2, a primary component in vascular remodeling. These results have broad implications for our understanding of postnatal brain plasticity, environmental modulation of behavior, and seasonal changes in brain function. 


\section{Introduction}

Adult mammalian brains have some level of plasticity; however, environmental contributors to brain plasticity remain poorly understood. Nontropical rodents display seasonal variation in many aspects of their physiology and behavior (for review, see Follett, 2015), providing attractive models in which to study brain plasticity, development, and natural variation (Vrana et al., 2014; Bedford and Hoekstra, 2015). White-footed mice (Peromyscus leucopus) are among the most well studied photoperiodic small rodents (Lynch, 1973; Johnston and Zucker, 1980; Demas et al., 1996; Walton et al., 2014; Sharp et al., 2015;). Many seasonal changes in their physiology and behavior are driven by predictable changes in photoperiod (day length) across the year. For instance, in response to autumnal short day (SD) lengths, many white-footed mice regress their reproductive systems and reputedly shift energy toward survival, although there is substantial variation among populations living at different latitudes (Dark et al., 1983; Pyter et al., 2005a). Pineal melatonin plays an important role in this process; most short photoperioddependent phenotypic changes can be recapitulated under long-photoperiod conditions via the administration of exogenous melatonin (Bartness et al., 1993; Goldman, 2001; Hiebert et al., 2006; Walton et al., 2013). Additionally, short days impair spatial learning and hippocampal long-term potentiation, reduce hippocampal volumes, alter hippocampal dendritic complexity, and reduce hippocampal neurogenesis (Pyter et al., 2005b; Walton et al., 2011, 2013, 2014). In tandem with changes in the hippocampus, white-footed mice alter neuronal spine densities within the basolateral amygdala in response to short photoperiods, and these changes are associated with enhanced fear memory (Walton et al., 2012).

These alterations in brain function are likely preceded or mirrored by changes in brain vascularity, as the brain is an energetically expensive organ (Engl and Attwell, 2015), and any reduction in size or vascular perfusion would confer significant energetic savings. To test this hypothesis, we maintained adult male $P$. leucopus mice in long-

Received February 24, 2016; accepted July 5, 2016; First published July 14, 2016

The authors declare no competing financial interests.

Author contributions: J.C.B., R.J.N., and C.R. designed research; J.C.B., S.T., S.G., and C.R. performed research; C.L.R. contributed unpublished reagents/analytic tools; J.C.B., S.T., S.G., and C.R. analyzed data; J.C.B., R.J.N., and C.R. wrote the paper.

This research was supported by National Science Foundation Division of Integrative Organismal Systems Grant 11-18792 to R.J.N., Presidential and Pelotonia Fellowships to J.C.B., and, in part, by American Heart Association Grant 12SDG11780023 to C.R.

Acknowledgments: We thank The Ohio State University Laboratory Animal Resource personnel for the excellent care they provided the animals used in these studies.

Correspondence should be addressed to Jeremy C. Borniger, The Ohio State University Wexner Medical Center, 636 Biomedical Research Tower, 460 West 12th Avenue, Columbus, $\mathrm{OH}$ 43210. E-mail: jeremy.borniger@osumc.edu.

DOl:http://dx.doi.org/10.1523/ENEURO.0058-16.2016

Copyright (C) 2016 Borniger et al.

This is an open-access article distributed under the terms of the Creative Commons Attribution 4.0 International, which permits unrestricted use, distribution and reproduction in any medium provided that the original work is properly attributed. or short-photoperiod conditions for 8 weeks, and then assessed capillary density and cerebral blood flow via fluorescein isothiocyanate (FITC)-lectin perfusion and laser speckle flowmetry (LSF). We further laser captured FITC $^{+}$hippocampal endothelial cells from brain tissue and assessed the expression of genes related to vascular remodeling. We predicted that animals maintained under short-day conditions would reduce cerebrovascular density and flow compared with their counterparts maintained in long day (LD) conditions, and changes in these measures would be accompanied by altered gene expression profiles in cerebral capillaries.

\section{Materials and Methods}

\section{Animals}

Adult ( $>8$ weeks old), male, white-footed mice ( $P$. leucopus) were purchased from the Peromyscus Genetic Stock Center (University of South Carolina, Columbia, SC; RRID: SCR_002769). These mice were born into longphotoperiod (16 h light/8 h dark) conditions and maintained in this lighting condition until shipment to our laboratory. Upon arrival at our facility, mice were allowed to recover from the stress of shipping and then assigned randomly to either SDs (8 $\mathrm{h}$ light/16 $\mathrm{h}$ dark) or LDs (16 $\mathrm{h}$ light/8 h dark). Mice were singly housed and maintained in their experimental lighting conditions for 8-9 weeks. Throughout the course of the experiment, mice were supplied with ad libitum filtered tap water and chow (catalog \#7912, Harlan Teklad), a cotton nestlet, and a piece of plastic housing enrichment. Weekly cage changes and body mass measures were the only physical disturbances throughout the experiment. Following each experiment, the brain (cohort 1), seminal vesicles (cohort 2), and paired testes were dissected. Organ masses were taken using an analytical balance (AE 240, Mettler Toledo). All procedures and experiments described below were approved by our affiliated Institutional Animal Care and Use Committee. Cohort 1 was used for lectin, immunohistochemistry, and laser capture experiments (described below). From this cohort, we originally started with 11 mice in the LD condition and 10 mice in the SD condition. During lectin perfusion, two LD mice had cardiac arrest prior to $5 \mathrm{~min}$ of lectin circulation and were excluded from analyses ( $L D=9$ ). Of the remaining mice in LD and SD conditions, four were randomly selected from each group for lectin visualization alone. The remaining samples were conserved to enable laser capture microdissection (LCM) studies. For LCM, sufficient sample from two SD lectin mice remained to include with untouched sample blocks (eight SD mice for LCM, five LD mice for LCM). After LCM, three blocks from the SD and LD groups remained for matrix metalloproteinase 2 (MMP2) staining of hippocampus (three SD mice for MMP2 staining, three LD mice for MMP2 staining). Cohort 2 was used for laser speckle flowmetry (LSF), where no mice were excluded from analyses (nine SD mice, eight LD mice). All mice were used for somatic and reproductive tissue measurements. Only mice in cohort 1 had their brains weighed, and only mice in cohort 2 had their seminal vesicles weighed, as this is 


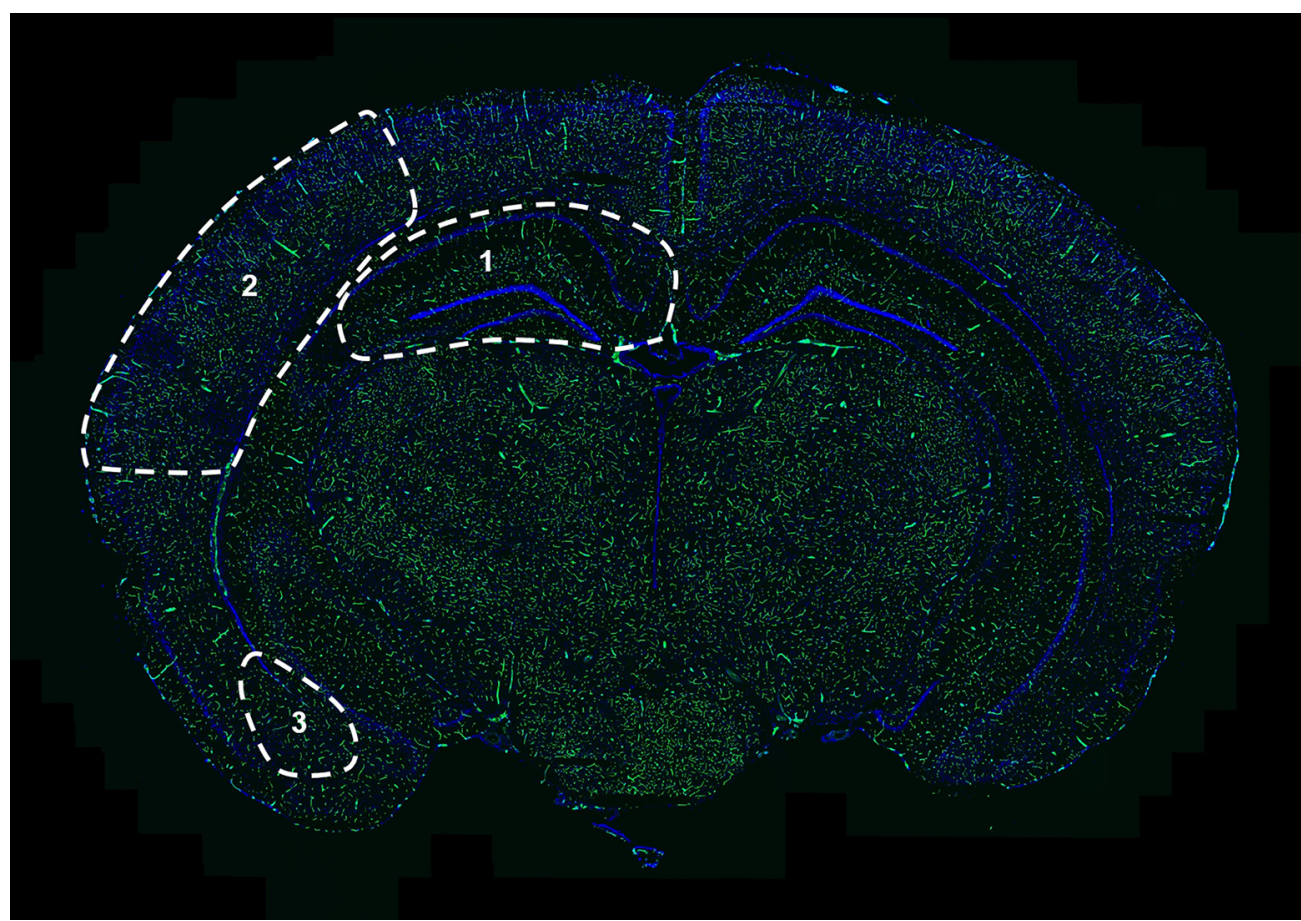

Figure 1. Representative $12 \mu \mathrm{m}$ coronal section of $P$. leucopus brain. Regions used for FITC-lectin blood vessel quantification are delineated as hippocampus (1), cortex (2), and amygdala (3). The section is counterstained with DAPI.

the most robust measure of reproductive regression in response to photoperiod.

\section{Blood vessel quantification}

After 8 weeks in their respective photoperiod conditions, mice were deeply anesthetized via intraperitoneal injection of $120 \mathrm{mg} / \mathrm{kg}$ ketamine and $24 \mathrm{mg} / \mathrm{kg}$ xylazine in a vehicle containing $0.9 \%$ sodium chloride. Upon sedation, mice were transcardially perfused with $250 \mu \mathrm{l}$ of FITC-tagged tomato (Lycopersicon esculentum) lectin over the course of $1 \mathrm{~min}(0.5 \mathrm{mg} / \mathrm{ml}$; Vector Laboratories). This lectin binds to complex-type $\mathrm{N}$-glycans glycoproteins found on the luminal surface of capillary endothelial cells, enabling morphological visualization and quantification specifically of capillary bed features (Robertson et al., 2015). This technique specifically allows for the visualization of patent (open) vessels and leaves inactive vessels unstained (Inai et al., 2004). Importantly, cerebral capillary density is recognized as a key variable in the study of brain angioplasticity in response to metabolic acclimatization (Boero et al., 1999; Benderro et al., 2012; Benderro and LaManna, 2014). To that end, our lectin perfusion approach was not designed for staining/quantification of large arteries or veins, but speaks to adaptive capillary remodeling in response to changes in photoperiod. FITClectin was allowed to circulate for $5 \mathrm{~min}$, after which the mouse was decapitated; and brains were dissected, weighed, embedded in O.C.T. compound (Sakura), and flash frozen in liquid nitrogen. Twelve micrometer serial sections were cut on a cryostat directly onto Superfrost Plus slides. DAPI was used as a nuclear counterstain. The FITC-lectin signal in the hippocampus, cortex, and amygdala (Fig. 1, representative image) was determined by a condition-blinded observer using the AutoMeasure plug-in within Axiovert software (version 4.8, Zeiss), as described previously (Khanna et al., 2013, 2015).

\section{Immunohistochemistry}

Immunohistochemical determination of MMP2 expression was performed as previously described (Rink et al., 2011; Khanna et al., 2013). Twelve micrometer sections were blocked in $10 \%$ normal goat serum, followed by an overnight $\left(4^{\circ} \mathrm{C}\right)$ incubation with primary antibody $(0.5 \mu \mathrm{g} / \mathrm{ml}$; anti-MMP2, Abcam; RRID:AB_10864041). Signal was visualized by reaction with fluorescent secondary antibody (30 min incubation at room temperature; goat anti-rabbit Alexa Fluor 568, Life Technologies). Sections were placed in DAPI for 5 min prior to being coverslipped. Images were captured using an Axiovert 200M microscope (Zeiss), and expression was quantified as the percentage area in hippocampus, amygdala, and S1 cortex regions of interest (ROIs) using the AutoMeasure plug-in within Axiovert software (version 4.8, Zeiss; Fig. 1). ROls were standardized across sections and localized using a mouse stereotaxic atlas (Paxinos and Franklin, 2004). Observation of no staining following omission of the primary antibody from the primary incubation acted as a negative control.

\section{Laser capture and quantitative PCR}

The $12-\mu \mathrm{m}$-thick sections for LCM were mounted onto RNase inhibitor-treated thermoplastic (polyethylene napthalate)-covered glass slides (PALM). FITC-lectin perfused blood vessels from the hippocampus were collected using MicroLaser, MicroBeam, and RoboStage/Robo- 
Table 1: Primer sequences used in qPCR

\begin{tabular}{|c|c|c|c|}
\hline Gene & Forward primer 5'-3' & Reverse primer 5'-3' & Tm \\
\hline Vegf & CCA GGC TGC ACC CAC GAC AG & TGA GGT GTG GGG GCT GCT GT & 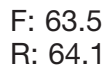 \\
\hline Hif1 $\alpha$ & CTG TGA TGA AAG AAT TAC TGA GTT GAT G & CAT AAA TTG AGC GGC CCA AA & $\begin{array}{l}F: 54.3 \\
R: 53.9\end{array}$ \\
\hline Tgf $\beta r 3$ & CAG GAC CAG CTC GAT GGA A & CAC CAG GAA GAG GTC TGT TGT TAT ACA & $\begin{array}{l}F: 56.9 \\
R: 58.0\end{array}$ \\
\hline Timp1 & CAG TCC CTG CCG CCA TCG TC & TGT GGG TGG AGT GGG GCA CA & 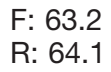 \\
\hline Mmp2 & CAC AAG TGG CCT GGG GAG CG & GCG TGG CTT CCG CAT GGT CT & $\begin{array}{l}F: 63.6 \\
R: 63.2\end{array}$ \\
\hline Csf2 & CTG CTC CCA CTC GCT CAC CC & AGG TTG CCC CGT AGG CCC TT & 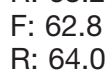 \\
\hline $18 s$ & GTA ACC CGT TGA ACC CCA TT & CCA TCC AAT CGG TAG TAG CG & $\begin{array}{l}F: 55.3 \\
R: 55.1\end{array}$ \\
\hline Nfh & CGA GCT GTA CGA GCG CGA GG & AGC TCG CCC ACC TCC TCC TG & $\begin{array}{l}F: 62.8 \\
R: 64.1\end{array}$ \\
\hline
\end{tabular}

F, Forward; R, reverse.

Mover systems (PALM). More than $100,000 \mu \mathrm{m}^{2}$ of capture elements were collected from each sample for downstream RNA isolation, cDNA synthesis, and quantitative PCR (qPCR). After laser cutting, the isolated vessels were catapulted directly into $35 \mu \mathrm{l}$ of RNA extraction buffer (PicoPure RNA Isolation Kit, Life Technologies) situated directly above the section in a microtube cap. An additional $15 \mu \mathrm{l}$ of extraction buffer was added after collection, and RNA was isolated from captured and catapulted elements. cDNA was synthesized from $>250 \mathrm{ng}$ of RNA using oligo-dT primer and Superscript III. cDNA was then quantified using SYBR Green-I in a real-time PCR reaction. Relative gene expression was standardized to $18 \mathrm{~S}$ ribosomal RNA expression. Primer sequences are available in Table 1. These genes were chosen because they are associated with vascular remodeling, and we have previously examined many of them in the context of reproductive regression in P. leucopus (Pyter et al., 2005a). Verification of endothelial cell enrichment in laser-captured samples was confirmed via high expression of Von Willebrand factor (MWF), and low expression of glial fibrillary acidic protein (GFAP) and neurofilament heavy (NFH).

\section{Laser speckle flowmetry}

A second subset of mice was housed in photoperiodic (8 $\mathrm{h}$ light/16 $\mathrm{h}$ dark and $16 \mathrm{~h}$ light/8 $\mathrm{h}$ dark) and housing conditions similar to those used in the first experiment. These mice were supplied tap water and food (catalog \#TD 01432-I, Harlan-Teklad, supplemented with fenbendazole) ad libitum. After 8-9 weeks in their respective photoperiod conditions, mice were deeply anesthetized in isoflurane $(4-5 \%$ induction, $1.5 \%$ maintenance) and positioned for laser speckle flowmetry. The skin of the scalp was cut along the sagittal plane to expose the braincase for imaging. A bolus of saline was applied to the skullcap to normalize the effect of light refraction between animals.
LSF recordings of the neocortex were acquired from a $1 \times$ $1 \mathrm{~cm}$ field of view using a $785 \mathrm{~nm}, 80 \mathrm{~mW}$ laser with a sampling rate of $60 \mathrm{~Hz}$ at a working distance of $10 \mathrm{~cm}$ (PeriCam PSI HR System, PeriMed). Relative perfusion units were averaged over a 10 s sampling period.

\section{Statistics}

Group means were compared using two-tailed independent-samples $t$ tests. If groups displayed unequal variances or data was non-normally distributed, nonparametric tests (i.e., Mann-Whitney $U$ test) were used. Statistical significance was set at $p \leq 0.05$. Statistics were completed with SPSS version 22 (IBM) and visualized using Prism version 5.0 (GraphPad Software). Table 2 contains more information regarding the statistical results presented.

\section{Results}

\section{Somatic and reproductive masses}

After 8 weeks in their respective photoperiod conditions, both cohorts of mice did not differ in body mass (cohort 1 : $t=1.596, p=0.126$; cohort $2: t=0.6, p=0.557$ ), brain mass (cohort 1: $t=0.913, p=0.373$ ), brain mass corrected for body mass (cohort 1: $t=0.126, p=0.901$ ), testes mass (cohort 1: $t=0.649, p=0.524$; cohort 2: $t=$ $1.196, p=0.250$ ), or mass of the seminal vesicles (cohort $2: t=0.672, p=0.512$; Fig. 2). These data indicate that reproductive responses to photoperiod were not apparent, suggesting a photoperiod-nonresponsive phenotype (Majoy and Heideman, 2000). Alternatively, previous reports have suggested that an exposure of 10-12 weeks elicits a maximal photoperiodic response (Pyter et al., 2005a; Walton et al., 2012). 
Table 2: Statistical table

\begin{tabular}{|c|c|c|c|c|}
\hline Figure & Panel & *Data structure & Test type & Observed powert/p value \\
\hline 2 & $A$ & Normal & $t$ test & $0.108 / p=0.476$ \\
\hline 2 & $B$ & Normal & $t$ test & $0.052 / p=0.901$ \\
\hline 2 & C & Normal & $t$ test & $0.097 / p=0.512$ \\
\hline 2 & $D$ & Normal & $t$ test & $0.238 / p=0.213$ \\
\hline 3 & $D$ (hippocampus) & Normal & $t$ test & $0.742 / p=0.02$ \\
\hline 3 & $D$ (cortex) & Non-normal & Mann-Whitney $U$ & $0.517 / p=0.029$ \\
\hline 3 & $D$ (amygdala) & Normal & $t$ test & $0.052 / p=0.871$ \\
\hline 4 & $B$ & Normal & $t$ test & $0.619 / p=0.027$ \\
\hline 5 & $A$ (MMP2) & Non-normal & Mann-Whitney $U$ & $0.635 / p=0.019$ \\
\hline 5 & $B$ & Normal & $t$ test & $1 / p=0.00019$ \\
\hline
\end{tabular}

*Normality tested using Shapiro-Wilk Test.

†Observed power calculated with G*Power version 3.1.7; statistical analyses were completed with SPSS Statistics (IBM) version 22.

\section{Short photoperiods reduce central capillary density and cerebral blood flow}

Mice maintained in short-day conditions had reduced FITC-lectin signal in the hippocampus (SD mean, 0.0108 \pm 0.003; LD mean, $0.0268 \pm 0.009 ; t=3.13, p=0.02$ ) and cortex (SD mean, $0.0232 \pm 0.015$; LD mean, 0.0775 $\pm 0.041 ; U=16, p=0.029$ ), but not the amygdala (SD mean, $0.033 \pm 0.0175$; LD mean, $0.0363 \pm 0.034 ; t=$ $0.169, p=0.871$; Fig. 3) compared with their LD counterparts. Furthermore, SD mice had an $\sim 15 \%$ reduction in cortical blood flow compared with their LD counterparts (SD mean, $311.95 \pm 52.44$; LD mean, $367 \pm 40.37 ; t=$ $2.442, p=0.027$; Fig. 4). These data provide evidence that short photoperiods decrease hippocampal and cortex capillary density, suggesting reduced cortical blood flow.

\section{Short photoperiods increase hippocampal MMP2 expression}

Hippocampal $\mathrm{FITC}^{+}$blood vessels from SD mice expressed higher levels of the gelatinase MMP2 (fold change from LD, $5.77 \pm 5.37 ; U=4, p=0.019$ ) compared with LD mice (Fig. 5C). No changes were detected in any of the other gene candidates examined $(p>0.05$ in all cases). Additionally, SD mice increased MMP2 expression in the hippocampus (Fig. 5B) compared with LD mice (SD mean, $0.069 \pm 0.0063$; LD mean, $0.02 \pm 0.00085 ; t=$ $13.18, p=0.00019)$. We focused on the hippocampus for these measures because a large amount of research has demonstrated short-day reductions in hippocampal function and hippocampal-dependent tasks (Pyter et al., 2005b; Walton et al., 2013). These data indicate that short-day exposed mice had greater hippocampal ex-
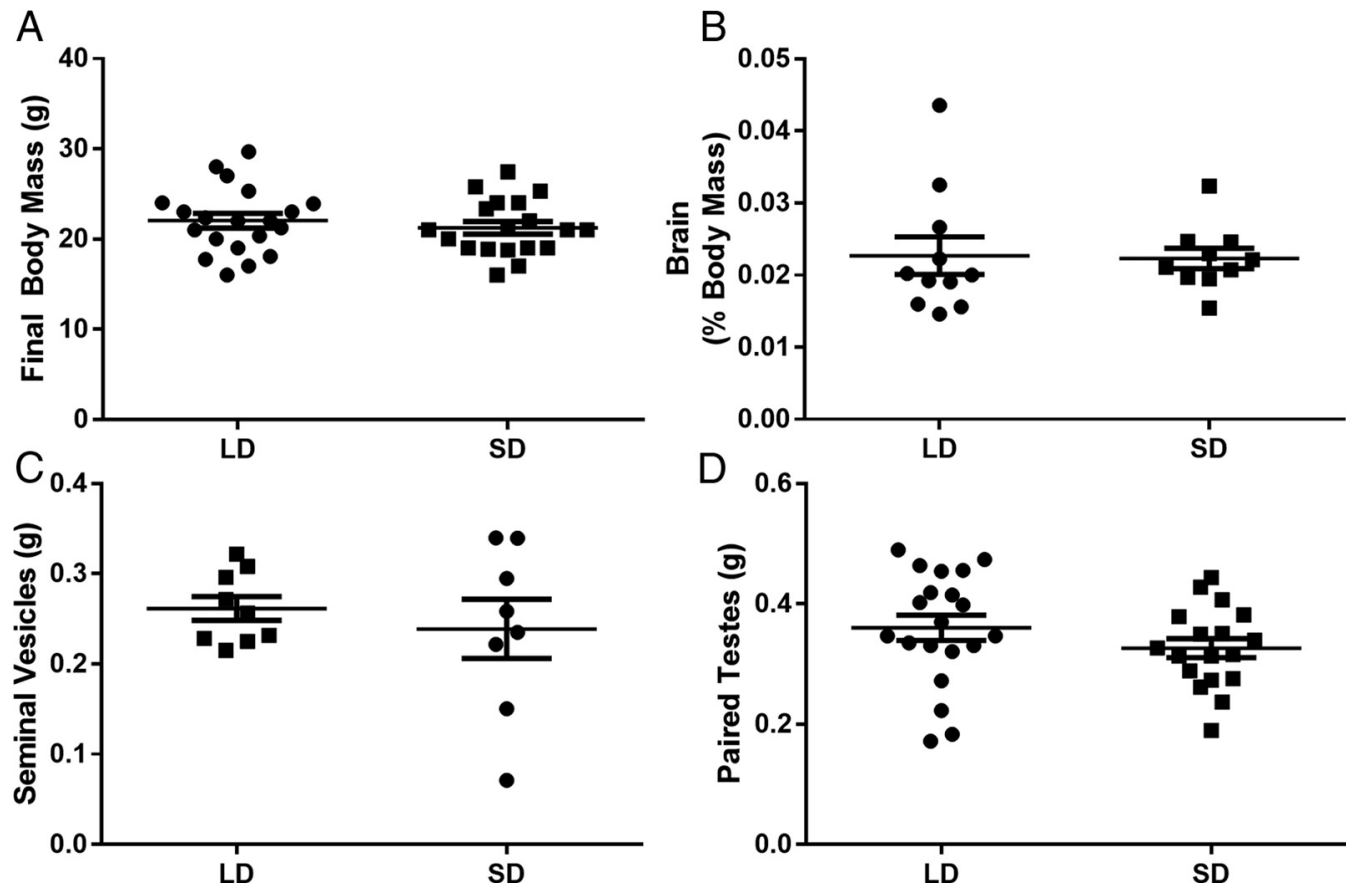

Figure 2. $\boldsymbol{A}-\boldsymbol{D}$, Eight weeks of short-day exposure did not cause gross body mass loss $(\boldsymbol{A})$, reduction in brain mass $(\boldsymbol{B})$, or reproductive regression $(\boldsymbol{C}, \boldsymbol{D})$, as measured by seminal vesicle and testes masses (note: brain weights were measured only for cohort 1 , and seminal vesicle weights were measured only for cohort 2). Error bars represent the SEM. 

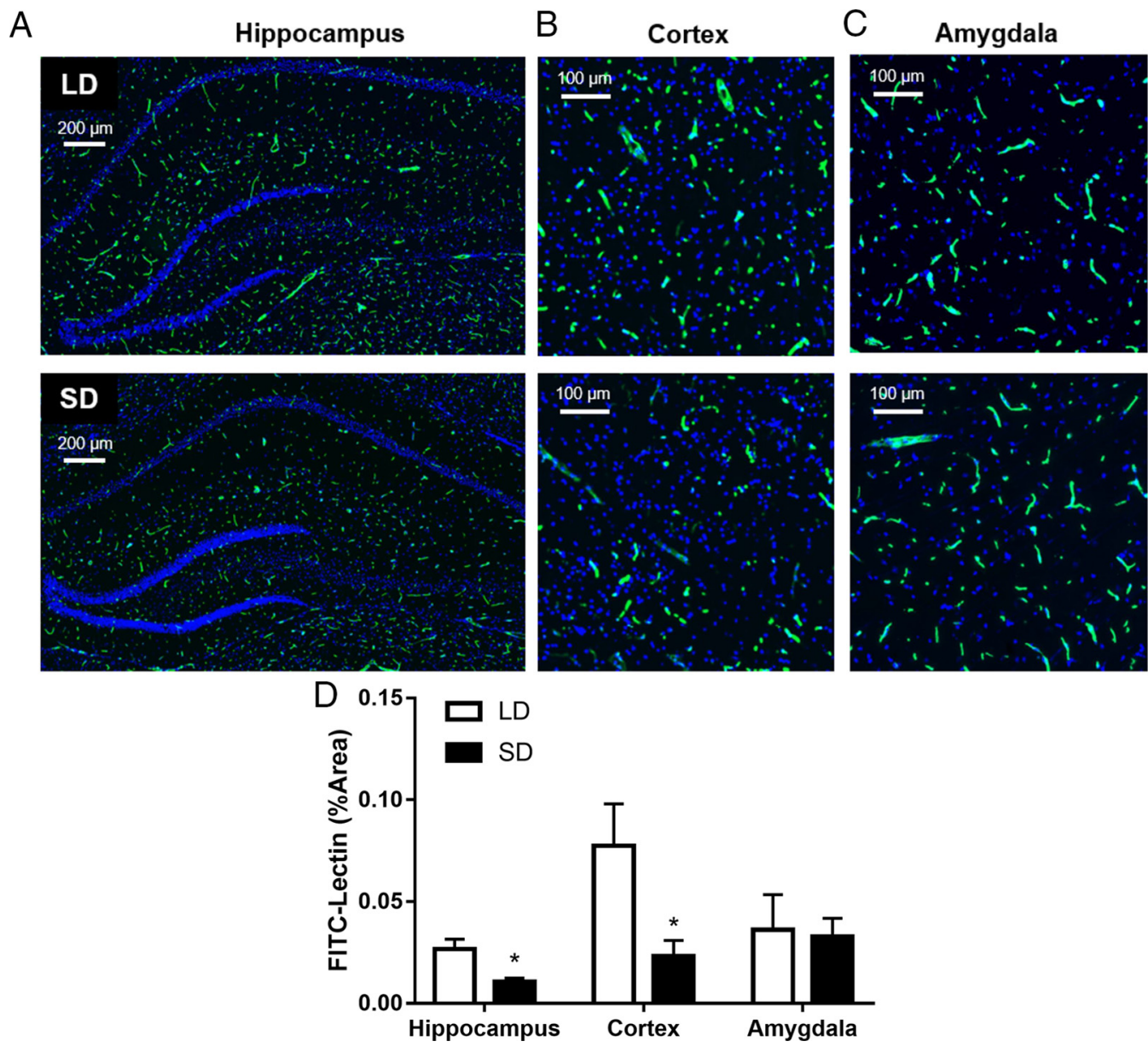

Figure 3. Short days reduce blood vessel density in the hippocampus and cortex. $\boldsymbol{A}-\boldsymbol{C}$, Representative images of hippocampus $(\boldsymbol{A})$, cortex $(\boldsymbol{B})$, and amygdala $(\boldsymbol{C})$ in LD (top row) and SD (bottom row) mice. Quantification of the mean \pm SEM per group are presented for these brain regions in $D$. $* p<0.05$. $N=4$ /group.

pression of MMP2 at the mRNA and protein level compared with LD mice.

\section{Discussion}

Together, these data demonstrate that day length can alter brain blood vessel dynamics in adult mammals. Mice maintained in short-day conditions had decreased cortical and hippocampal perfusion (Figs. 3, 4) and increased MMP2 mRNA expression in brain capillaries and MMP2 in the brain parenchyma (Fig. 5).

Previous research has examined other environmental contributors that increase central blood vessel formation. It is well documented that environmental enrichment or motor activity can increase central angiogenesis and synaptogenesis in rats (Black et al., 1987, 1990; Sirevaag et al., 1988; Ding et al., 2006). Environmental contributors that decrease central blood flow, however, remain undefined. P. leucopus display seasonal changes in cognitive capacity; short days decrease performance on hippocampal dependent tasks, hippocampal neurogenesis, and dendritic spine densities (Pyter et al., 2005b; Walton et al., 2014). Our data suggest that this phenomenon is accompanied by capillary remodeling in the hippocampus and cortex; thus, short-day reductions in blood flow may pre- cede declines in brain function. It is important to note that due to limitations in the penetration depth of the laser speckle instrument, we were unable to reliably measure hippocampal-specific blood flow using this method. However, changes in blood flow within the hippocampus are evident as FITC-lectin binds only active capillary beds when administered via transcardial perfusion, leaving inactive blood vessels unstained. Additionally, because our lectin perfusion method selectively stains capillary beds (Robertson et al., 2015), it was important to test whether changes in these microvessels resulted in measurable changes in blood flow.

Regulation of testicular angiogenesis in $P$. leucopus has been studied in the context of photoperiod-induced changes in reproduction. In the testes, short days trigger the expression of Hif1 $\alpha$, Serpine1, and Tgf $\beta r 3$, inhibiting angiogenesis and halting reproductive function during testicular regression (Pyter et al., 2005a). Reduced blood flow to the brain coincident with gonadal regression may allow for animals to trade off reproductive function and cognitive capacity for somatic maintenance and thermogenesis during the impending winter months. We found no evidence of reproductive regression in the present 
A
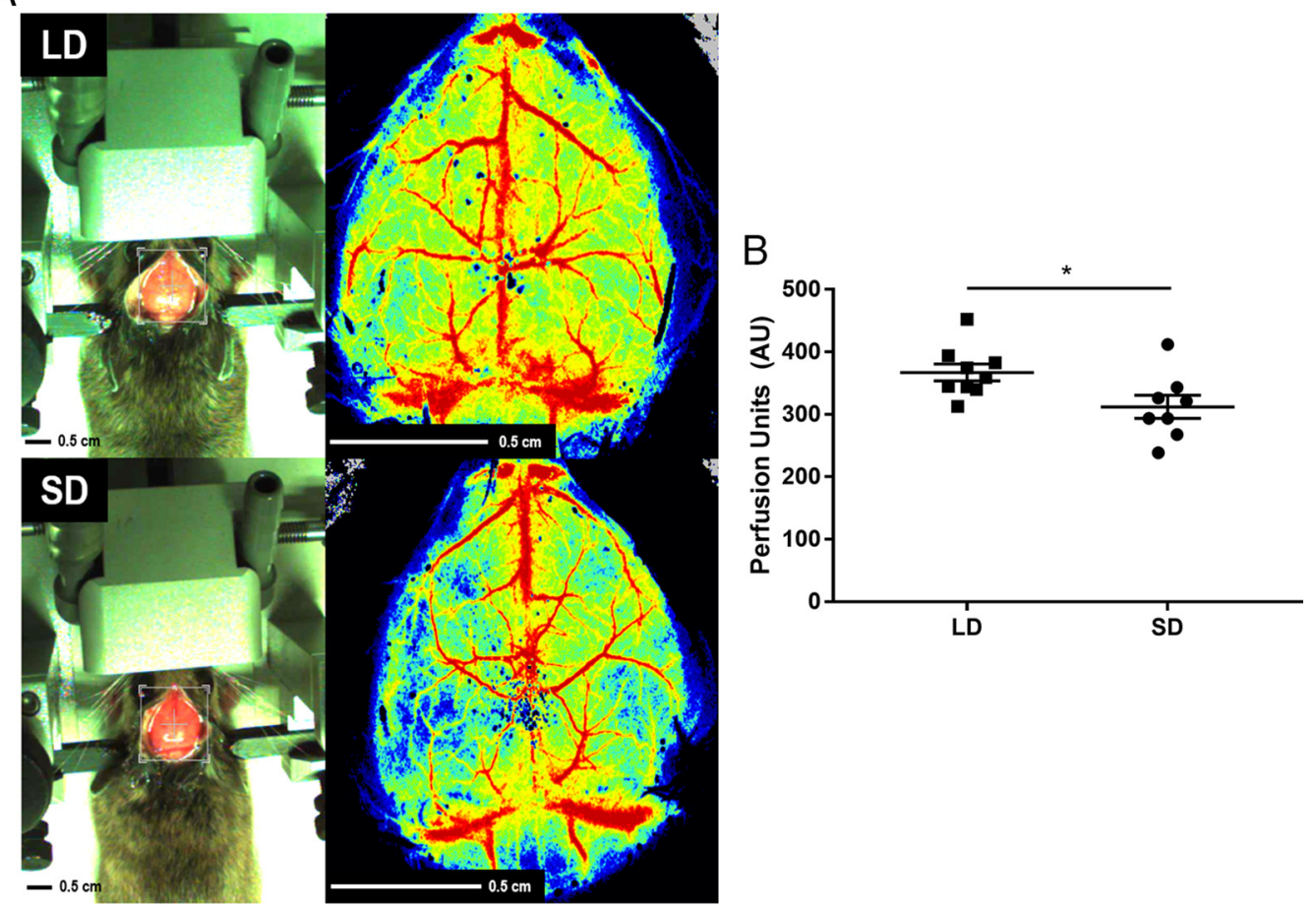

Figure 4. Short days reduce cerebral blood flow by $\sim 15 \%$. $\boldsymbol{A}$, Representative speckle contrast images of the brain of an LD and an SD mouse. B, Quantification of relative perfusion units between LD and SD animals. $N=9$ LD, 8 SD. Error bars represent the SEM. $* p<0.05$.

study, indicating that changes within the brain can occur independently from photoperiodic regulation of the reproductive system.

MMPs act to degrade a variety of extracellular matrix proteins and participate in vessel remodeling, apoptosis, cell migration, proliferation, and host defense (Chakraborti et al., 2003). MMP2 (gelatinase A) primarily catalyzes the breakdown of type IV collagen, a component of endothelial basement membranes. In the brain, MMP2 can be produced by neurons, glia, and endothelial cells (Planas et al., 2001). It also plays a large role in endometrial remodeling during menses and the regulation of vascularization in response to immune activation (Freitas et al., 1999; Parks et al., 2004). MMP2 is specifically implicated in seasonal changes in reproductive function in Siberian hamsters (Phodopus sungorus), another seasonally breeding small rodent (Salverson et al., 2008; Shahed et al., $2015 a, b)$. In this species, MMP2 facilitates photostimulated ovarian recrudescence after extended short-day exposure. That is, MMP2 is rapidly induced in the ovaries after transfer from short to long photoperiods. It is interesting to note that MMP2 in the ovaries of $P$. sungorus is elevated in response to long photoperiods, while in the brains of $P$. leucopus that were used in our study it was increased in response to short photoperiods. Although widely implicated in angiogenesis, the initial steps of MMP2 action involve the fragmentation of the capillary basal lamina, leading to downstream migration of endothelial cells in response to angiogenic factors (Sang, 1998). In P. leucopus, the initial steps of basement mem- brane breakdown occur (as evidenced by increased MMP2 expression), but the subsequent formation of functional blood vessels seems to be impaired in SD mice (reduced FITC-lectin signal). In support of this, we found no evidence of increased vascular endothelial growth factor (VEGF) expression in short-day mouse brain endothelium (Fig. 5A).

In sum, our data demonstrate a role of photoperiod in the regulation of central blood flow in an adult mammal. Further experiments should address whether the transition back into a long photoperiod reverses short dayinduced vessel reductions, the time course of blood vessel remodeling, and the role that melatonin or other seasonally regulated molecules play in the phenotype we observed. Additionally, these data provide an impetus for investigating seasonal rhythms in cardiovascular disease (Ricci et al., 1992; Sheth et al., 1999), because the short days of winter may be an overlooked but important contributor, although this remains to be determined. It is important to note that our data represent a "snapshot" of the dynamic changes occurring in response to short photoperiods; and because we did not observe reproductive regression, our findings may represent an intermediate phenotype. However, independent photoperiodic regulation of the reproductive system and the brain has been described in a closely related species of California mice (Peromyscus californicus), where short photoperiods induce aggressive behavior without reproductive regression, a phenotype that can be recapitulated with the administration of exogenous melatonin (Nelson et al., 

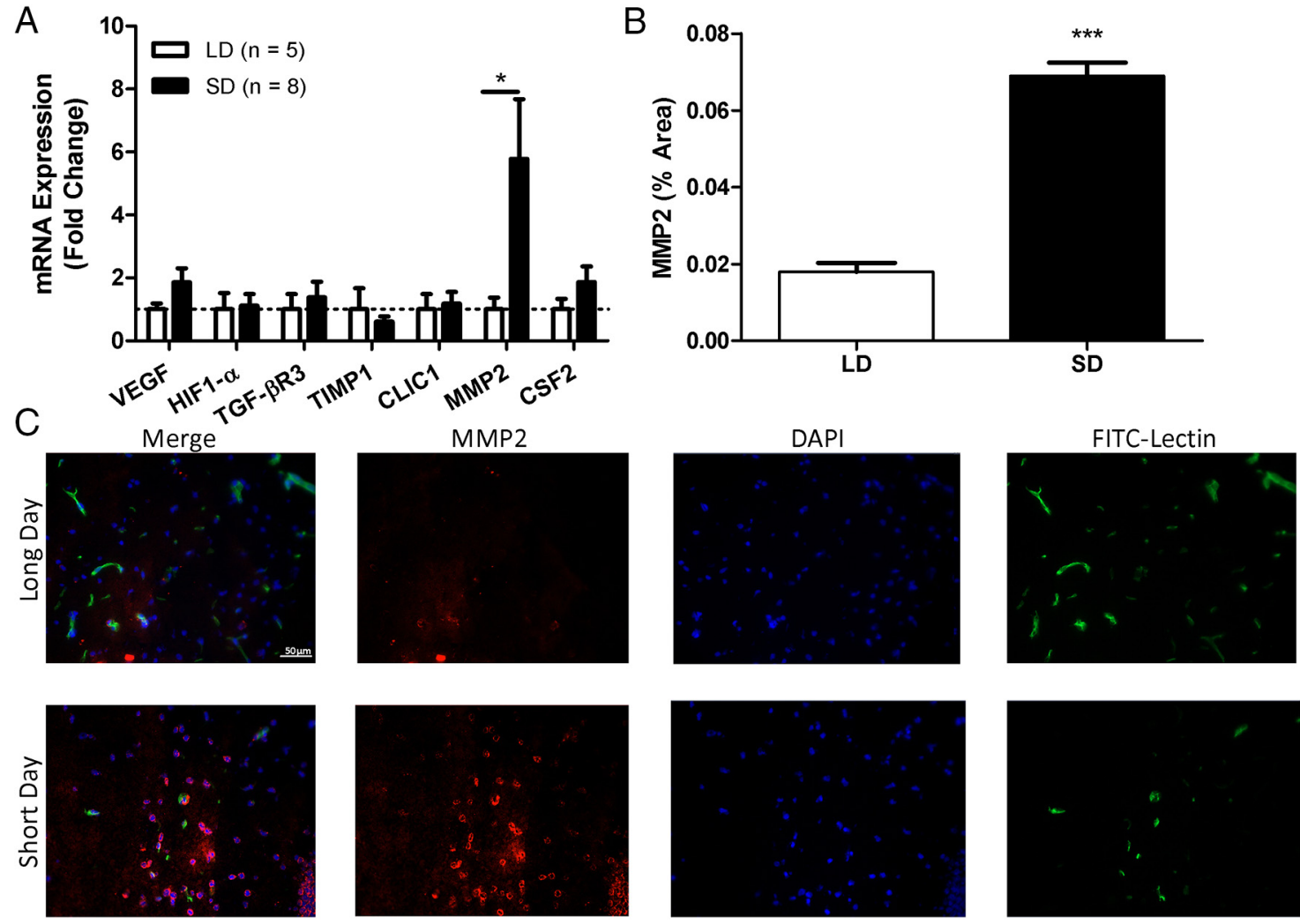

Figure 5. Short days increased MMP2 mRNA expression in brain endothelial cells and MMP2 protein in the hippocampus. A, Gene expression in laser-captured hippocampal FITC ${ }^{+}$endothelial cells reveal higher MMP2 expression in short days. $\boldsymbol{B}$, Immunohistochemical quantification of MMP2 staining in hippocampus ( $N=3$ /group). $C$, Representative immunofluorescent images of an LD and an SD housed mouse stained with anti-MMP2 primary Ab, DAPI, and FITC-lectin. Error bars represent the SEM. $* p<0.05, * * * p<$ 0.001 .

1995; Laredo et al., 2014). Additionally, there is high heritability in reproductive nonresponsiveness to short photoperiods in P. leucopus (Heideman et al., 1999), and photoperiodic responsiveness within the same Peromyscus species depends on their latitude of origin (Dark et al., 1983). Furthermore, short photoperiod-induced changes in hippocampal neurogenesis are evident in as few as 2 weeks of short-photoperiod exposure, well before reproductive regression occurs (Walton et al., 2014). These data indicate that changes within the CNS of Peromyscus species can be uncoupled from alterations in the reproductive system.

\section{References}

Bartness TJ, Powers JB, Hastings MH, Bittman EL (1993) The timed infusion paradigm for melatonin delivery: what has it taught us about the melatonin signal, its reception, and the photoperiodic control of seasonal responses? J Pineal Res 15:161-190. Medline Bedford NL, Hoekstra HE (2015) Peromyscus mice as a model for studying natural variation. eLife 4:e06813. CrossRef Medline

Benderro GF, LaManna JC (2014) HIF-1 $\alpha /$ COX-2 expression and mouse brain capillary remodeling during prolonged moderate hypoxia and subsequent re-oxygenation. Brain Res 1569:41-47. CrossRef Medline

Benderro GF, Sun X, Kuang Y, LaManna JC (2012) Decreased VEGF expression and microvascular density, but increased HIF-1 and $2 \alpha$ accumulation and EPO expression in chronic moderate hyperoxia in the mouse brain. Brain Res 1471:46-55. CrossRef Medline
Black JE, Sirevaag AM, Greenough WT (1987) Complex experience promotes capillary formation in young rat visual cortex. Neurosci Lett 83:351-355. Medline

Black JE, Isaacs RK, Anderson BJ, Alcantara AA, Greenough WT (1990) Learning causes synaptogenesis, whereas motor activity causes angiogenesis, in cerebellar cortex of adult rats. Proc Natl Acad Sci U S A 87:5568-5572. CrossRef

Boero JA, Ascher J, Arregui A, Rovainen C, Woolsey TA (1999) Increased brain capillaries in chronic hypoxia. J Appl Physiol 86:1211-1219. Medline

Chakraborti S, Mandal M, Das S, Mandal A, Chakraborti T (2003) Regulation of matrix metalloproteinases: an overview. Mol Cell Biochem 253:269-285. Medline

Dark JO, Johnston PG, Healy M, Zucker IR (1983) Latitude of origin influences photoperiodic control of reproduction of deer mice (Peromyscus maniculatus). Biol Reprod 28:213-220. Medline

Demas GE, Klein SL, Nelson RJ (1996) Reproductive and immune responses to photoperiod and melatonin are linked in Peromyscus subspecies. J Comp Physiol A 179:819-825. Medline

Ding YH, Li J, Zhou Y, Rafols JA, Clark JC, Ding Y (2006) Cerebral angiogenesis and expression of angiogenic factors in aging rats after exercise. Curr Neurovasc Res 3:15-23. Medline

Engl E, Attwell D (2015) Non-signalling energy use in the brain. J Physiol 593:3417-3429. CrossRef Medline

Follett BK (2015) "Seasonal changes in the neuroendocrine system": some reflections. Front Neuroendocrinol 37:3-12. CrossRef Medline

Freitas S, Meduri G, Le Nestour E, Bausero P, Perrot-Applanat M (1999) Expression of metalloproteinases and their inhibitors in blood vessels in human endometrium. Biol Reprod 61:1070-1082. Medline 
Goldman BD (2001) Mammalian photoperiodic system: formal properties and neuroendocrine mechanisms of photoperiodic time measurement. J Biol Rhythms 16:283-301. Medline

Heideman PD, Bruno TA, Singley JW, Smedley JV (1999) Genetic variation in photoperiodism in Peromyscus leucopus: geographic variation in an alternative life-history strategy. J Mammal 80:12321242. CrossRef

Hiebert SM, Green SA, Yellon SM (2006) Daily timed melatonin feedings mimic effects of short days on testis regression and cortisol in circulation in Siberian hamsters. Gen Comp Endocrinol 146:211-216. CrossRef Medline

Inai $T$, Mancuso $M$, Hashizume $H$, Baffert $F$, Haskell A, Baluk $P$, Hu-Lowe DD, Shalinsky DR, Thurston G, Yancopoulos GD, McDonald DM (2004) Inhibition of vascular endothelial growth factor (VEGF) signaling in cancer causes loss of endothelial fenestrations, regression of tumor vessels, and appearance of basement membrane ghosts. Am J Pathol 165:35-52. CrossRef Medline

Johnston PG, Zucker I (1980) Photoperiodic regulation of reproductive development in white-footed mice (Peromyscus leucopus). Biol Reprod 22:983-989. Medline

Khanna S, Rink C, Ghoorkhanian R, Gnyawali S, Heigel M, Wijesinghe DS, Chalfant CE, Chan YC, Banerjee J, Huang Y, Roy S, Sen CK (2013) Loss of miR-29b following acute ischemic stroke contributes to neural cell death and infarct size. J Cereb Blood Flow Metab 33:1197-1206. CrossRef Medline

Khanna S, Heigel M, Weist J, Gnyawali S, Teplitsky S, Roy S, Sen CK, Rink C (2015) Excessive $\alpha$-tocopherol exacerbates microglial activation and brain injury caused by acute ischemic stroke. FASEB J 29:828-836. CrossRef Medline

Laredo SA, Orr VN, McMackin MZ, Trainor BC (2014) The effects of exogenous melatonin and melatonin receptor blockade on aggression and estrogen-dependent gene expression in male California mice (Peromyscus californicus). Physiol Behav 128:86-91 CrossRef Medline

Lynch GR (1973) Seasonal changes in thermogenesis, organ weights, and body composition in the white-footed mouse, Peromyscus leucopus. Oecologia Dec 1;13 (4):363-376.

Majoy SB, Heideman PD (2000) Tau differences between short-day responsive and short-day nonresponsive white-footed mice (Peromyscus leucopus) do not affect reproductive photoresponsiveness. J Biol Rhythms 15:501-513. CrossRef

Nelson RJ, Gubernick DJ, Blom JMC (1995) Influence of photoperiod, green food, and water availability on reproduction in male California mice (Peromyscus californicus). Physiol Behav 57:11751180 Medline

Parks WC, Wilson CL, López-Boado YS (2004) Matrix metalloproteinases as modulators of inflammation and innate immunity. Nat Rev Immunol 4:617-629. CrossRef Medline

Paxinos G, Franklin KB (2004) The mouse brain in stereotaxic coordinates. Houston, TX: Gulf Professional Publishing.

Planas AM, Solé S, Justicia C (2001) Expression and activation of matrix metalloproteinase- 2 and -9 in rat brain after transient focal cerebral ischemia. Neurobiol Dis 8:834-846 CrossRef Medline

Pyter LM, Hotchkiss AK, Nelson RJ (2005a) Photoperiod-induced differential expression of angiogenesis genes in testes of adult Peromyscus leucopus. Reproduction 129:201-209. CrossRef Medline

Pyter LM, Reader BF, Nelson RJ (2005b) Short photoperiods impair spatial learning and alter hippocampal dendritic morphology in adult male white-footed mice (Peromyscus leucopus). J Neurosci 25:4521-4526. CrossRef Medline

Ricci S, Celani MG, Vitali R, La Rosa F, Righetti E, Duca E (1992) Diurnal and seasonal variations in the occurrence of stroke: a community-based study. Neuroepidemiology 11:59-64. Medline

Rink C, Christoforidis G, Khanna S, Peterson L, Patel Y, Khanna S, Abduljalil A, Irfanoglu O, Machiraju R, Bergdall VK, Sen CK (2011) Tocotrienol vitamin $\mathrm{E}$ protects against preclinical canine ischemic stroke by inducing arteriogenesis. J Cereb Blood Flow Metab 31:2218-2230 CrossRef Medline

Robertson RT, Levine ST, Haynes SM, Gutierrez P, Baratta JL, Tan Z, Longmuir KJ (2015) Use of labeled tomato lectin for imaging vasculature structures. Histochem Cell Biol 143:225-34. CrossRef Medline

Salverson TJ, McMichael GE, Sury JJ, Shahed A, Young KA (2008) Differential expression of matrix metalloproteinases during stimulated ovarian recrudescence in Siberian hamsters (Phodopus sungorus). Gen Comp Endocrinol 155:749-761. CrossRef Medline

Sang A (1998) Complex role of matrix metalloproteinases in angiogenesis. Cell Res 8:171-177. CrossRef Medline

Shahed A, Simmons JJ, Featherstone SL, Young KA (2015a) Matrix metalloproteinase inhibition influences aspects of photoperiod stimulated ovarian recrudescence in Siberian hamsters. Gen Comp Endocrinol 216:46-53. CrossRef Medline

Shahed A, McMichael CF, Young KA (2015b) Rapid changes in ovarian mRNA induced by brief photostimulation in Siberian hamsters (Phodopus sungorus). J Exp Zool A Ecol Gen Physiol 323: 627-636. CrossRef Medline

Sharp K, Bucci D, Zelensky PK, Chesney A, Tidhar W, Broussard DR, Heideman PD (2015) Genetic variation in male sexual behaviour in a population of white-footed mice in relation to photoperiod. Anim Behav 104:203-212. CrossRef Medline

Sheth T, Nair C, Muller J, Yusuf S (1999) Increased winter mortality from acute myocardial infarction and stroke: the effect of age. $J$ Am Coll Cardiol 33:1916-1919. Medline

Sirevaag AM, Black JE, Shafron D, Greenough WT (1988) Direct evidence that complex experience increases capillary branching and surface area in visual cortex of young rats. Dev Brain Res 43:299-304. CrossRef

Vrana PB, Shorter KR, Szalai G, Felder MR, Crossland JP, Veres M, Allen JE, Wiley CD, Duselis AR, Dewey MJ, Dawson WD (2014) Peromyscus (deer mice) as developmental models. Dev Biol 3:211-230. CrossRef Medline

Walton JC, Chen Z, Weil ZM, Pyter LM, Travers JB, Nelson RJ (2011) Photoperiod-mediated impairment of long-term potention and learning and memory in male white-footed mice. Neuroscience 175:127-132 CrossRef Medline

Walton JC, Haim A, Spieldenner JM, Nelson RJ (2012) Photoperiod alters fear responses and basolateral amygdala neuronal spine density in white-footed mice (Peromyscus leucopus). Behav Brain Res 233:345-350. CrossRef Medline

Walton JC, Chen Z, Travers JB, Nelson RJ (2013) Exogenous melatonin reproduces the effects of short day lengths on hippocampal function in male white-footed mice, Peromyscus leucopus. Neuroscience 248:403-413. CrossRef Medline

Walton JC, Aubrecht TG, Weil ZM, Leuner B, Nelson RJ (2014) Photoperiodic regulation of hippocampal neurogenesis in adult male white-footed mice (Peromyscus leucopus). Eur J Neurosci 40:2674-2679. CrossRef Medline 